\title{
Traumatic cerebral contusion: pathobiology and critical aspects
}

\author{
Hernando Alvis-Miranda, Gabriel Alcala-Cerra, \\ Luis Rafael Moscote-Salazar
}

Universidad de Cartagena

\begin{abstract}
Traumatic brain injury is a major cause of mortality in developed countries. Cerebral parenchymal injury is evidenced by a significant percentage of patients. The most important structural lesion of the brain is the cerebral contusion, which is a complex and dynamic area, a result of the primary lesion and which is associated with ischemic and inflammatory phenomena that need to be known by the neurosurgeon. We present a review of the most important aspects of brain contusion.
\end{abstract}

Key words: brain contusion, focal traumatic brain injuries, traumatic brain injury.

\section{Introduction}

Traumatic brain injury (TBI) is an important public health problem and is the leading cause of mortality, morbidity, and disabilities in children and young adults, especially in young males (15-35 years old) (1). Internationally, TBI accounts for significant socio-economic implications; in the US alone, over 1.7 M individuals suffer a TBI each year (2). One of the main characteristic of TBI is that patients without a severe TBI, can experience subsequent mental and/or medical problems $(3,4)$. The acute consequences of TBI are just only a half of the complete problem, the long- term repercussions of TBI are substantial especially among adolescents and young adults, whose brains continue to mature and develop (5).

Focal brain injury, is defined as a localised damage to the brain in form of laceration, contusion and haematoma occurring in the presence or absence of a skull opening from either a pre-trauma trephination or a mechanic fracture caused by the impact itself (6). From the focal brain injuries, cerebral contusions (CC) are one of the most common traumatic findings, being present in up to $31 \%$ of initial imaging studies (CT-scans) of patients with TBI (7). It has been reported that contusions occurred in $89 \%$ of brains examined postmortem (8).

$\mathrm{CC}$ is a type of focal TBI, resulting from direct loading and often occurs in the absence of widespread injury (9), representing focal regions of traumainduced subpial hemorrhage and swelling, zones of cellular injury where the microvasculature is also disrupted (10). Pure CC are fairly common, found in $8 \%$ of all TBI $(11,12)$ and $13 \%$ to $35 \%$ of severe injuries (11).

The vast majority of contusions occur in the frontal and temporal lobes, although they can occur at almost any site, including the cerebellum and brainstem (13). Ratnaike et al (14) founded retrospectively 
that most blows causing CC are to back of the head, being most contusions contrecoup lesions affecting the frontal and temporal lobes. Any intracranial contusion, as other focal injuries such as hematoma, or brain laceration falls within the category of severe TBI (15).

This work aims to review critical aspects of CC in clinical practice, such as pathophysiology, diagnosis and management.

\section{Characterization}

CC are more common in regions that contact bony surfaces in the cranial vault during trauma: frontal and temporal poles, orbitofrontal gyri, perisylvian cortices, and inferolateral temporal lobe surfaces (16). Contusions can be characterized by mechanism, anatomic location, or adjacent injuries. Table 1 summarizes main characteristics of each one.

\section{Pathophysiology}

In TBI, the primary injury to the brain is caused by the initial mechanical impact, resulting in skull fracture, $\mathrm{CC}$, and vascular and parenchymal injury causing intracranial bleed and ICH. An inflammatory process, edema formation, and excitotoxicity follow, resulting in further increase in ICP and reduced cerebral perfusion pressure $(\mathrm{CPP})$ $(17,18)$.

Despite the prevalence of such injury, the injury mechanism leading to $\mathrm{CC}$ has long been studied but still remains unclear. As part of TBI, CC is a complex neurological event that results in the disruption of numerous cellular and physiological processes (19).

\section{Biomechanical forces}

TBI results from the transfer of energy from the environment to brain tissue that is greater than the amount that can be absorbed without dysfunction. Traumatic insults generally occur over short periods of time and are referred to as dynamic loading, and includes both direct or impact loading, as well as impulsive loading whereby no physical contact occurs (9).

TABLE 1

\section{Characterization of cerebral contusions}

\begin{tabular}{|l|l|}
\hline $\begin{array}{l}\text { Fracture } \\
\text { contusions }\end{array}$ & $\begin{array}{l}\text { Result from direct contact injuries and occur immediately adjacent to a } \\
\text { skull fracture. }\end{array}$ \\
\hline Coup contusions & Refer to those that occur at the site of impact in the absence of a fracture. \\
\hline $\begin{array}{l}\text { Contrecoup } \\
\text { contusions }\end{array}$ & Are those that are diametrically opposite to the point of impact. \\
\hline $\begin{array}{l}\text { Gliding } \\
\text { contusions }\end{array}$ & $\begin{array}{l}\text { Are focal hemorrhages involving the cortex and adjacent white matter of } \\
\text { the superior margins of the cerebral hemispheres; they are due to } \\
\text { rotational mechanisms rather than contact forces. }\end{array}$ \\
\hline $\begin{array}{l}\text { Intermediary } \\
\text { contusions }\end{array}$ & $\begin{array}{l}\text { Are lesions that affect deep brain structures, such as the corpus callosum, } \\
\text { basal ganglia, hypothalamus, and brainstem. }\end{array}$ \\
\hline $\begin{array}{l}\text { Herniation } \\
\text { contusions }\end{array}$ & $\begin{array}{l}\text { Can occur in areas where the medial parts of the temporal lobe contact } \\
\text { the tentorial edge (i.e., uncal herniation) or where the cerebellar tonsils } \\
\text { contact the foramen magnum (i.e., tonsillar herniation). }\end{array}$ \\
\hline Adapted from (16) & \multicolumn{2}{|l}{} \\
\hline
\end{tabular}


The loads absorbed by the brain after trauma generally include linear and rotational components called angular loads. The rate and duration of the insult are important because loads applied at high rates tend to result in more damage (9).

$\mathrm{CC}$ and other focal injuries result from direct loading and often occurs in the absence of widespread injury (9).

Pericontusional zone (PCZ) is recognized as the rim of edematic nonnecrotic tissue surrounding the central necrotic core in the acute phase of traumatic cerebral contusion (20). PCZ has the potential to cause prolonged and deteriorated neurological and neuropsychological change (20).

There have been arguments regarding whether intracranial pressure (ICP) or tissue strain causes CC (21). Traditionally, positive (compressive) ICP has been believed to induce CC under the impact site (22).

Cerebral and systemic changes induced by cerebral contusion

Following TBI, an abundance of biochemical events is directed to the ensuing brain parenchyma destruction.

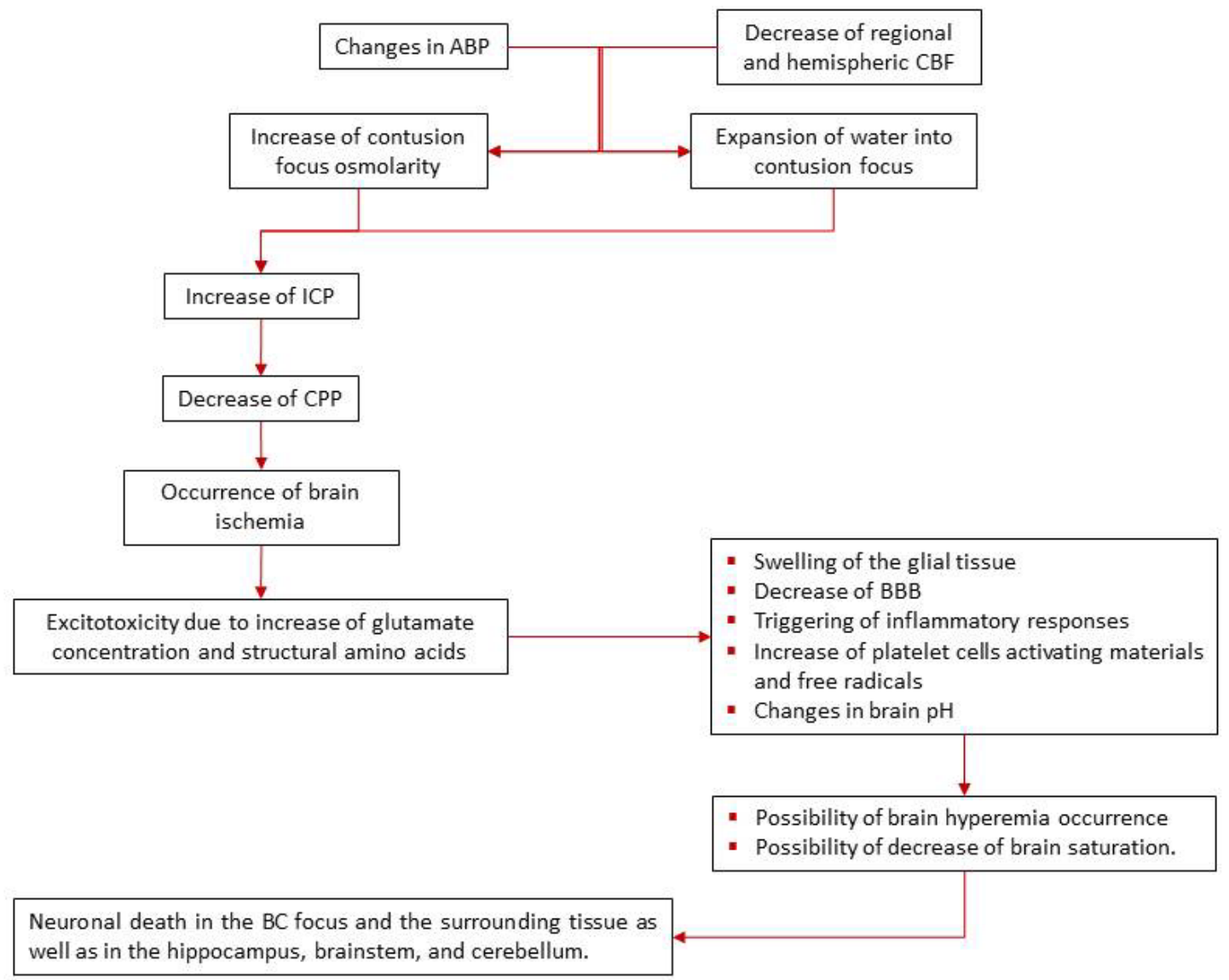

Figure 1 Schematic cascade of events triggered by TBI Adapted from (24) 
Focal vascular alterations restrict the delivery of substrates to the brain such as oxygen and glucose, driving to energy depletion, ionic gradients that are necessary to maintaining membrane potential are lost, resulting in neuronal and glial depolarizations (23).

The pathogenesis of CC results from interrelated multifactorial phenomena involving anatomical and functional microcirculatory alterations; all are a continuum of deleterious effects that drives brain parenchyma to suffering and death, Figure 1, schematizes these effects.

TBI is associated with a cerebral inflammatory response characterized by microglial and astrocytic activation, as well as release of inflammatory mediators (25).

Pro-inflammatory cytokines such as IL$1 \beta$, IL- 6 and TNF- $\alpha$ have been linked to the early events mediating BBB breakdown and subsequent development of cerebral edema (26).

TNF- $\alpha$ directly disturbs BBB integrity, leading to cerebral edema and leukocyte infiltration (27).

\section{Vascular Alteration - Cerebral Blood Flow and Perfusion}

Head trauma causes rupture of cerebral small blood vessels at an early period, especially in white matter. Spasm of the larger cerebral arteries after head trauma has been postulated in several works to be the main cause of cerebral ischemia; however, measurements of cerebral blood volume are more compatible with compromised microcirculation in the cerebral tissue (28). Ischemia and contusion are directly correlated with the severity of the injury (29-31). Unfortunately the contusionassociated microvascular alterations have been inadequately studied (32); this is due to the fact that researches focused mainly on alterations in the neural tissue, giving less emphasis to the mechanisms that give rise to ischemic brain damage. However the evidence indicates that three major factors are involved, these are (32):

1. Increases in the intercellular cytosolic calcium concentration

\section{Acidosis}

3. Free radical production

In severe TBI, CPP, which is defined as the difference between mean arterial pressure and ICP, at a level lower than 70 $\mathrm{mmHg}$ serves as a clinical threshold for adverse outcome (33).

In 1957, Freytag and Lindenberg demonstrated two components of CC: the central core area in which cells undergo necrosis and the peripheral (rim) area in which cellular swelling occurs (34) Hacer Imágen.

In the central core area, the CBF is 4.7 $\mathrm{ml} / 100 \mathrm{~g} / \mathrm{min}$, and of $16-18 \mathrm{ml} / 100 \mathrm{~g} / \mathrm{min}$ in the peripheral zone (24).

Normally, CBF is $>50 \mathrm{ml} / 100 \mathrm{~g} / \mathrm{min}$, and the ischemic threshold is commonly considered to be $18-20 \mathrm{ml} / 100 \mathrm{~g} / \mathrm{min}$ (3537).

The decrease of ABP, the development of $\mathrm{ICH}$, and decrease in CPP are related to disturbances in blood vessel sensitivity in the hypoperfusional zone $(36,38-40)$.

In the clinical setting, low GCS associated with vasospasm has reported deficiencies in cerebral perfusion (41).

The low cerebral perfusion following TBI is accompanied by a parallel decrease in BTpO2 (42).

Katayama et al have reported that blood flow decreases 3 hours after the harmful event, implying the impact of adequate treatment and permanent multimodal monitoring to prevent expansion of this zone into the normal brain (43). 
This zone can encompass approximately $15 \%$ of brain hemisphere, and in patients with poorer outcome can be very extensive, encompassing a large part of brain hemisphere $(36,44-48)$.

However, Lebedev et al. reported cases of hypoperfusional zone reduction (49), thus a good clinical management can avoid the increase of this zone and its expansion into the normal brain, preventing an irretrievable brain damage.

Schröder et al, demonstrated in 1995 the absence of reperfusion in this zone (39).

The reduction of CBF may be due to vasoconstriction through the synthesis of endothelin-1 (50) on upregulated endothelin receptors $\mathrm{A}$ and $\mathrm{B}$ on blood vessels and neurons (51). Conversely, a recent finding suggests that arteriolar diameters may increase and that the perceived decrease in vasculature may be due to thrombogenesis which can form within $1 \mathrm{~h}$ of injury (52).

\section{Impairment of cerebral autoregulation}

$\mathrm{BC}$ is likely to cause severe damage in cerebral autoregulation. Cerebral or pressure autoregulation is the inherent ability of blood vessels to keep CBF relatively constant over a wide range of arterial blood pressure (ABP) or cerebral perfusion pressure levels by the interplay of numerous physiological mechanisms (37,53), mainly active variations of cerebrovascular resistance. Once the autoregulatory mechanisms have been abolished, CBF passively follows changes in $\mathrm{ABP}$ and impaired cerebral pressure. Under these conditions, the brain becomes vulnerable to ischemic or hyperemic injuries if perfusion pressure does not remain coupled with metabolic demands (37)

$\mathrm{ABP}, \mathrm{ICP}$, and $\mathrm{CBF}$ measurements provide important data about cerebral autoregulation (54-56).

Cerebral vascular autoregulation would recover on the fourth day after severe TBI, and CPP might be increased by recovery of autoregulation. Thus, subsequent nonemergent surgery should be performed at least 4 days after severe TBI to prevent secondary brain injury. In addition, it should be kept in mind that the cerebral vulnerability might persist for 4 days after suffering severe TBI (57).

\section{Excitotoxicity}

In moderate-severe TBI, the initial trauma from the brain injury can lead to immediate cell death through necrosis where the cell lyses and releases noxious substances such as inflammatory chemokines and cytokines, reactive oxygen species (ROS) and proteases.

Changes in markers of metabolic impairment can occur before the onset of $\mathrm{ICH}$, suggesting that biochemical impairment can be present before low cerebral perfusion pressure is detectable (58).

In particular, glutamate excitotoxicity is a contributor to cellular damage after injury (59) as it can cause persistent membrane depolarization, resulting in ion dyshomeostasis and consequent cell death (33), also its coagonist aspartate, and structural amino acids (threonine and valine) have been involved in parenchyma microdialysis probes or in cerebrospinal fluid (CSF) as associated excitotoxic aminoacids $(60,61)$. These aminoacids have been linked to the causation of both acute and chronic neuronal damage. As has been mentioned, increase of glutamate persistently activates ion channels, particularly N-methyl-D-aspartate channel. The dysregulation will affect the 
physiological processes of the cortex and the hippocampus, because of their dependency regard to this aminoacid $(60,62)$. As consequence of the permanent opening of N-methyl-D-aspartate channels, sodium and calcium penetrate into cells while potassium is extrude to the extracellular space.

The consequences of ion dysregulation are velocity dependent, when happens rapid, it can result in massive accumulation of intracellular calcium with rapid neuronal death that can occur during the first day after the trauma, this process is also called "fast excitotoxicity" (24). When calcium entry is retarded neuronal death can be traced within the period of 5-7 days after the injury (63). The extruded potassium into the extracellular space causes a rapid swelling of astrocytes. This can, in turn, lead to "cytotoxic edema," which is thought to cause ICH.

The blockage of glutamate by $\mathrm{N}$ methyl-D-aspartate channel antagonists decreases the secondary damage of neuronal cells $(64,65)$. Clearly the more severe brain damage, the higher the increase of glutamate (63).

Heterogeneous mechanisms exist in early edema formation in $\mathrm{CC}$, and cytotoxic edema plays an important role within 48 hours post-trauma; this early cellular swelling in the peripheral area begins within 6 hours following injury, a fact suggesting that the CBF does not decrease to ischemic level immediately following injury (66).

\section{Brain Ischemia}

CC can be accompanied by altered hemodynamic states, which can aggravate the initial traumatic injury, conducing to ischemia (63), Table 2 summarizes some hemodynamic states and its definitions.
TABLE 2

Altered hemodynamic states related to brain ischemia due to $\mathrm{CC}$

\begin{tabular}{|l|l|}
\hline \multicolumn{1}{|c|}{ STATE } & \multicolumn{1}{c|}{ CHARACTERISTIC } \\
\hline Hypoxemia & PaO2 $<60 \mathrm{~mm} \mathrm{Hg}$ \\
\hline Hypotension & $\begin{array}{l}<50 \mathrm{mmHg} \text { for }>30 \mathrm{~min} . \\
\text { prior to resuscitation }\end{array}$ \\
\hline $\begin{array}{l}\text { Mean arterial } \\
\text { blood pressure } \\
\text { (MABP) }\end{array}$ & $\begin{array}{l}\text { Hemispheric } \mathrm{CBF}<20 \\
\mathrm{ml} / 100 \mathrm{~g} / \mathrm{min}\end{array}$ \\
\hline Herniation & Fixed dilated pupil \\
\hline CPP & $<50 \mathrm{~mm} \mathrm{Hg}$ for $>30 \mathrm{~min}$ \\
\hline
\end{tabular}

Several authors have suggested that cerebral ischemia or infarction can occur despite adequate control of ICP and CPP (67-70). When glutamates increase up to 50-100 $\mathrm{mmol} / \mathrm{L}$, neuronal death can be detected within several hours due to their overexcitation (24). CC is crucial for the behavior of glutamate and for the increase of structural amino acids (threonine and valine) resulting from neuronal death. When combining ischemic events with CC the result is a more severe secondary neuronal damage.

\section{Edema formation}

Brain edema formation is a secondary injury caused by a cascade of mechanisms initiated at the moment of injury (71). In Table 3 are listed the phases of brain edema due to CC. ICH is a frequent complication of severe TBI (72-74), near to $70 \%$ of brain injured patients will present ICH (75-78). Life threatening episodes of raised ICP are usually associated with conditions that afflict wide areas of the brain such as global cerebral swelling after a trauma (79). Patients suffering from CC often develop edema and HIC with a delayed onset, which causes impairment in neurological function and sometimes herniation although no further bleeding has occurred (80). After the traumatic event, local 
damage and $\mathrm{BBB}$ breakdown lead to neurochemical mediator release and regional changes in cerebral edema $(71,81)$.

The genesis of brain swelling in an area of CC implies multiple, but conventionally considered to result from a combination of vasogenic and cytotoxic edema mechanisms (83):

- Vasogenic edema results from the breakdown of the blood brain barrier and extravasations of fluid into the extracellular space, which sets in only after 12-24 hrs (84)

- Cytotoxic edema is the consequence of a hypoxic insult resulting in membrane pump failure and cellular swelling. It can occur early, but its quantum is insufficient to explain the mass effect that is clinically encountered.

As mentioned, the early swelling around a CC which occurs in the first 24 hours and is often life threatening, cannot be explained by either of these factors.

It appears that the capacity for edema fluid accumulation increases in the central area and resistance for edema fluid propagation is elevated by cellular swelling in the peripheral area (83). During the initial 2-3 days following TBI brain edema expands from the core, incorporating to the perilesional uninjured tissue (82).

\section{Imaginological appearance}

CC appears as heterogeneous areas of brain necrosis, hemorrhage, and infarction and represents mixed-density lesions on brain-CT scan. Multiple focal contusions have a "salt and pepper" appearance on CT. However the distinction between contusions and traumatic intracerebral hematomas remains difficult to define. A "salt and pepper" lesion is clearly a CC, but a large hematoma clearly is not. There is a gray zone, and contusions can, over a period of hours or days, evolve into intracerebral hematomas (13).

Due to the absence of CT-scan CC classification, we propose one, which consider three types $(1-3)$ each one with two subtypes ( $a$ or $b$ ) taking considerations of size, uni/bilaterally location and mass effect, as described in Table 4.

TABLE 3

Brain edema phases in CC

\begin{tabular}{|l|l|}
\hline \multicolumn{1}{|c|}{ Phase } & \multicolumn{1}{c|}{ Characteristics } \\
\hline $\begin{array}{l}\text { Frist phase or ultra- } \\
\text { early phase }\end{array}$ & $\begin{array}{l}\text { Occurs within the first 24 hours and is often the cause of clinical } \\
\text { deterioration or death. }\end{array}$ \\
\hline $\begin{array}{l}\text { Second phase or } \\
\text { delayed phase }\end{array}$ & $\begin{array}{l}\text { Sets in after 24 to 72 hours and progresses for 7-10 days. } \\
\text { This swelling rarely contributes to clinically significant ICH. }\end{array}$ \\
\hline Third phase & $\begin{array}{l}\text { Sets in with the lysis of RBC in the intracerebral clot. } \\
\text { Hemoglobin breakdown products activate reactive oxygen species, trigger } \\
\text { cytokines (mainly IL6 and IL10) and activate the complement system } \\
\text { (mainly C3d and C9) }\end{array}$ \\
\hline \multicolumn{2}{|l|}{ Adapted from $(10,82)$}
\end{tabular}


CC are characterized by mixed densities of lesions, which are commonly surrounded by perilesional hypodense areas in close contact with the internal surface of the skull (85). Inhomogeneity (a major therapeutic challenge) is often reflected on the initial CT scan by a salt and pepper appearance. Although there is little debate that hyperdense regions represent hemorrhagic areas that can be safely evacuated, the significance of surrounding hypodense regions stills controversial (7).

TABLE 4

Proposal of cerebral contusion imaginological (brain CT-scan) classification

\begin{tabular}{|c|c|l|}
\hline \multicolumn{2}{|c|}{ Type } & \multicolumn{1}{c|}{ Description } \\
\hline \multirow{2}{*}{1} & $\mathbf{a}$ & $\begin{array}{l}\text { Lobar microcontusions or cerebral } \\
\text { contusions }<1 \mathrm{~cm}\end{array}$ \\
\cline { 2 - 3 } & $\mathbf{b}$ & $\begin{array}{l}\text { Bilateral lobar microcontusions or } \\
\text { cerebral contusions }\end{array}$ \\
\hline \multirow{2}{*}{$\mathbf{2}$} & $\mathbf{a}$ & Unilateral lobar contusions \\
\cline { 2 - 3 } & $\mathbf{b}$ & Bilateral lobar contusions \\
\hline \multirow{2}{*}{$\mathbf{3}$} & $\mathbf{a}$ & $\begin{array}{l}\text { Hemispheric contusions with severe } \\
\text { unilateral mass effect }\end{array}$ \\
\cline { 2 - 3 } & $\mathbf{b}$ & $\begin{array}{l}\text { Hemispheric contusions with severe } \\
\text { bilateral mass effect }\end{array}$ \\
\hline
\end{tabular}

\section{Management}

Because of CC tendency to enlarge over time and become significant space occupying lesions, it could leads rapidly to $\mathrm{ICH}$ with subsequent clinical deterioration or worsening neurological condition $(7,85$, 86), thus CC can become a major therapeutic challenge with critical functional importance whenever surgical removal of the lesion is contemplated in neurologically eloquent areas (7).

CC treatment, as in others severe TBI, evolves rapidly with the addition of new technologies. Traditionally, therapeutic treatment of TBI relied on strict monitoring and augmentation of ICP, MAP and CPP, but currently the guidelines from the Brain Trauma Foundation have recommended initiating treatment for ICP values greater than 20 and maintaining CPP between 50 and $70 \mathrm{mmHg}$ in order to improve outcomes (87). According to the clinical practice guidelines in severe TBI of Taiwan (88), one of the indications for ICP (grade B) monitors may be used on patients with severe TBI (GCS score 3-8) with abnormal CT scan findings, which include CC, hematomas, brain edema, and compressed basal cisterns, but also in the case of severe TBI with normal CT-scan findings but with at least 2 of the following conditions: (a) $\geq 40$ years old; (b) unilateral or bilateral decerebrate or decorticated posture; (c) systolic blood pressure $<90$ $\mathrm{mm} \mathrm{Hg}$; and can be considered individually for mild or moderate TBI.

There are high-risk patients for convulsions, which can aggravate its neurological deficit extremely rapidly, which include those with the GCS score $\leq 10$, cortical contusion, depressed skull fractures, subdural hematoma, epidural hematoma, intracerebral hemorrhage, penetrating head injury, and epileptic seizures within 24 hours after injury (88), thus in these patients, anticonvulsants medications should be considered.

Regard to surgical intervention, there still remain some debate about its value in the evacuation of intraparenchymal lesions, such as CC (89). Currently is a readiness to surgically evacuate extraparenchymal hematomas but regard to intraparenchymal lesions have been adopted a conservative approach (89). The rationale include the removal of the edema which is producing osmotic load and also abolishing of necrotic 
and apoptotic cascades triggered off by the products of blood degradation. CC surgical excision is best done conservatively with minimal or absent trauma to surrounding tissue, and ideally done through a limited and optimally placed cortical incision. In the case of hemorrhagic necrotic brain tissue may be sucked out through an appropriately placed pial-cortical window. However conservative contusectomies are best combined with a decompressive craniectomy.

As a tool for the reduction of ICP, decompressive craniectomy (DC) is very effective (90-92). The procedure aims at negating the pressure volume relationship of the closed cranial cavity. DC per se does not tackle the pathological brain swelling. However, increasing the size of the container it alleviates the effects of raised intracranial pressure. DC is indicated in a patient with a GCS score $\leq 13$ or less with a midline shift of more than $5 \mathrm{~mm}$. Bifrontal DC may be used to decrease ICP in cases with generalized edema and central herniation.

To remember, progression of hemorrhage/contusion $(5 \%-58 \%)$ is a potential complications arising from DC $(93,94)$.

\section{Conclusions}

$\mathrm{CC}$ is a dynamic and expansive process having pronounced effects not only in the vicinity of the contusion focus but also in more remote areas (hippocampus and the brain stem). CC has the tendency to enlarge over time and become significant space occupying lesions; it could leads rapidly to $\mathrm{ICH}$ with subsequent clinical deterioration or worsening neurological condition. It can cause severe damage in cerebral autoregulation, leading to suffering parenchymal zones. Because had been reported reduction of hypoperfusional zone it is comprehensible that good clinical management can avoid the increase of this zone and its expansion into the sourrounding normal brain. Unfortunately the data regard to specifically CC is scarce, it is needed further concepts standardizations to give the best care to TBI patients.

Correspondence:

Dr. Luis Rafael Moscote

Universidad de Cartagena, Colombia.

e-mail:mineurocirujano@aol.com

\section{References}

1.Arabi YM, Haddad S, Tamim HM, Al-Dawood A, AlQahtani S, Ferayan A, Al-Abdulmughni I, Al-Oweis J, Rugaan A. Mortality reduction after implementing a clinical practice guidelines-based management protocol for severe traumatic brain injury. J Crit Care 2010;25:190-5

2.Faul M, Xu L, Wald M, Coronado V. Traumatic brain injury in the United States: Emergency department visits, hospitalizations and deaths 2002-2006. Atlanta, GA: Centers for Disease Control and Prevention 2010. 3.Galarneau MR, Woodruff SI, Dye JL, Mohrle CR, Wade AL. Traumatic brain injury during Operation Iraqi Freedom: findings from the United States NavyMarine Corps Combat Trauma Registry. J Neurosurg 2008;108:950-7.

4.Okie S. Traumatic brain injury in the war zone. $\mathrm{N}$ Engl J Med 2005;352:2043-7.

5.Pujol J, Vendrell P, Junqué C, Martí-Vilalta JL, Capdevila A. When does human brain development end? Evidence of corpus callosum growth up to adulthood. Ann Neurol 1993;34:71-5.

6.Morganti-Kossmann MC, Yan E, Bye N. Animal models of traumatic brain injury: Is there an optimal model to reproduce human brain injury in the laboratory? Injury 2010;41, Supple:S10-S13.

7.Soustiel JF, Mahamid E, Goldsher D, Zaaroor M. Perfusion-CT for early assessment of traumatic cerebral contusions. Neuroradiology 2008;50:189-96.

8.Cooper P. Post-traumatic intracranial mass lesions. In: PR C, editor. Head Injury, Lippincott Williams \& Wilkins; 1982.

9.Blyth BJ, Bazarian JJ. Traumatic alterations in consciousness: traumatic brain injury. Emerg Med Clin 
N Am 2010;28:571-94.

10.Mathai KI, Sengupta SK, Shashivadhanan, Sudumbrekar SM. Surgery for cerebral contusions: Rationale and practice. The Indian Journal of Neurotrauma 2009;6:17-20.

11.Mandera M, Zralek C, Krawczyk I, Zyciński A, Wencel T, Bazowski P. Surgery or conservative treatment in children with traumatic intracerebral haematoma. Childs Nerv Syst 1999;15:267-9; discussion 270.

12.Bullock MR, Chesnut R, Ghajar J, Gordon D, Hartl R, Newell DW, Servadei F, Walters BC, Wilberger J. Surgical management of traumatic parenchymal lesions. Neurosurgery 2006;58:S25-46; discussion Si-iv.

13.Houseman C, Belverud S, Narayan R. Closed Head Injury. In: Ellenbogen $\mathrm{R}$, Abdulrauf $\mathrm{S}$, editors. Principels of neurological surgery, Philadelphia: Saunders Elsevier; 2012, pp. 325-47.

14.Ratnaike TE, Hastie H, Gregson B, Mitchell P. The geometry of brain contusion: relationship between site of contusion and direction of injury. British Journal of Neurosurgery 2011;25:410-3.

15.Heegaard $\mathrm{W}$, Biros $M$. Traumatic brain injury. Emerg Med Clin N Am 2007;25:655-78, viii.

16.Shahlaie K, Zwienenberg-Lee M, Muizelaar JP. Clinical Pathophysiology of Traumatic Brain Injury. In: Bullock MR, Hovda DA, editors. Youmans neurological surgery, Saunders Elsevier; 2011, pp. 3362-79.

17.Greve MW, Zink BJ. Pathophysiology of traumatic brain injury. Mt Sinai J Med 2009;76:97-104.

18.Werner C, Engelhard K. Pathophysiology of traumatic brain injury. Br J Anaesth 2007;99:4-9.

19.Degeorge ML, Marlowe D, Werner E, Soderstrom KE, Stock M, Mueller A, Bohn MC, Kozlowski DA. Combining glial cell line-derived neurotrophic factor gene delivery AdGDNF. with L-arginine decreases contusion size but not behavioral deficits after traumatic brain injury. Brain Research 2011;1403:45-56.

20.Bao Y-J, Li L-Z, Li X-G, Wang Y-J. 17Beta-estradiol differentially protects cortical pericontusional zone from programmed cell death after traumatic cerebral contusion at distinct stages via non-genomic and genomic pathways. Molecular and Cellular Neurosciences 2011;48:185-94.

21.Huang HM, Lee MC, Lee SY, Chiu WT, Pan LC, Chen CT. Finite element analysis of brain contusion: an indirect impact study. Med Biol Eng Comput 2000;38:253-9.

22.King AI. Fundamentals of impact biomechanics: Part I--Biomechanics of the head, neck, and thorax. Annu Rev Biomed Eng 2000;2:55-81.

23.Golding EM. Sequelae following traumatic brain injury: The cerebrovascular perspective. Brain Research Reviews 2002;38:377-88.
24.Ragaisis V. [Brain contusion: morphology, pathogenesis and treatment]. Medicina Kaunas. 2002;38:243-9; quiz 354.

25.Alvis-Miranda HR, Alcala-Cerra G, Moscote-Salazar LR. Microglia: roles and rules in brain traumatic injury. Romanian Neurosurgery 2013;XX:34-45.

26.Ramilo O, Sáez-Llorens X, Mertsola J, Jafari H, Olsen KD, Hansen EJ, Yoshinaga M, Ohkawara S, Nariuchi H, McCracken GH. Tumor necrosis factor alpha/cachectin and interleukin 1 beta initiate meningeal inflammation. J Exp Med 1990;172:497-507.

27.Megyeri P, Abrahám CS, Temesvári P, Kovács J, Vas $\mathrm{T}$, Speer CP. Recombinant human tumor necrosis factor alpha constricts pial arterioles and increases blood-brain barrier permeability in newborn piglets. Neurosci Lett 1992;148:137-40.

28.Rodríguez-Baeza A, Reina-de la Torre F, Poca A, Martí M, Garnacho A. Morphological features in human cortical brain microvessels after head injury: a three-dimensional and immunocytochemical study. Anat Rec A Discov Mol Cell Evol Biol 2003;273:58393.

29.Park E, Bell JD, Siddiq IP, Baker AJ. An analysis of regional microvascular loss and recovery following two grades of fluid percussion trauma: a role for hypoxiainducible factors in traumatic brain injury. Journal of Cerebral Blood Flow and Metabolism : Official Journal of the International Society of Cerebral Blood Flow and Metabolism 2009;29:575-84.

30.Rafols JA, Kreipke CW, Petrov T. Alterations in cerebral cortex microvessels and the microcirculation in a rat model of traumatic brain injury: a correlative EM and laser Doppler flowmetry study. Neurological Research 2007;29:339-47.

31.Hekmatpanah J, Hekmatpanah CR. Microvascular alterations following cerebral contusion in rats. Light, scanning, and electron microscope study. Journal of Neurosurgery 1985;62:888-97.

32.Daneyemez M. Microangiographic changes following cerebral contusion in rats. Neuroscience 1999;92:783-90.

33.Kan EM, Ling E-A, Lu J. Microenvironment changes in mild traumatic brain injury. Brain Res Bull 2012;87:359-72.

34.Freytag E, Lindenberg R. Morphology of cortical contusions. AMA Arch Pathol 1957;63:23-42.

35.Depreitere B, Aviv R, Symons S, Schwartz M, Coudyzer W, Wilms G, Marchal G. Study of perfusion in and around cerebral contusions by means of computed tomography. Acta Neurochir Suppl 2008;102:259-62.

36.McLaughlin MR, Marion DW. Cerebral blood flow and vasoresponsivity within and around cerebral contusions. J Neurosurg 1996;85:871-6. 
37.Bor-Seng-Shu E, Kita WS, Figueiredo EG, Paiva WS, Fonoff ET, Teixeira MJ, Panerai RB. Cerebral hemodynamics: concepts of clinical importance. Arq Neuropsiquiatr 2012;70:352-6.

38.Schalén W, Messeter K, Nordström CH. Cerebral vasoreactivity and the prediction of outcome in severe traumatic brain lesions. Acta Anaesthesiol Scand 1991;35:113-22.

39.Schröder ML, Muizelaar JP, Bullock MR, Salvant JB, Povlishock JT. Focal ischemia due to traumatic contusions documented by stable xenon-CT and ultrastructural studies. J Neurosurg 1995;82:966-71.

40.Shiina G, Onuma T, Kameyama M, Shimosegawa Y, Ishii K, Shirane R, Yoshimoto T. Sequential assessment of cerebral blood flow in diffuse brain injury by 123Iiodoamphetamine single-photon emission CT. AJNR Am J Neuroradiol 1998;19:297-302.

41.Shahlaie K, Boggan JE, Latchaw RE, Ji C, Muizelaar JP. Posttraumatic vasospasm detected by continuous brain tissue oxygen monitoring: treatment with intraarterial verapamil and balloon angioplasty. Neurocrit Care 2009;10:61-9.

42.Jaeger $M$, Dengl $M$, Meixensberger J, Schuhmann MU. Effects of cerebrovascular pressure reactivityguided optimization of cerebral perfusion pressure on brain tissue oxygenation after traumatic brain injury. Crit Care Med 2010;38:1343-7.

43. Katayama Y, Mori T, Maeda T, Kawamata T. Pathogenesis of the mass effect of cerebral contusions: rapid increase in osmolality within the contusion necrosis. Acta Neurochir Suppl 1998;71:289-92.

44.McD Anderson R, Opeskin K. Timing of early changes in brain trauma. Am J Forensic Med Pathol 1998;19:1-9.

45.Adelson PD, Whalen MJ, Kochanek PM, Robichaud $\mathrm{P}$, Carlos TM. Blood brain barrier permeability and acute inflammation in two models of traumatic brain injury in the immature rat: a preliminary report. Acta Neurochir Suppl 1998;71:104-6.

46.Baldwin SA, Fugaccia I, Brown DR, Brown L V, Scheff SW. Blood-brain barrier breach following cortical contusion in the rat. J Neurosurg 1996;85:47681.

47.Lewén A, Fredriksson A, Li GL, Olsson Y, Hillered L. Behavioural and morphological outcome of mild cortical contusion trauma of the rat brain: influence of NMDA-receptor blockade. Acta Neurochir Wien. 1999;141:193-202.

48.Yamaki T, Murakami N, Iwamoto Y, Sakakibara T, Kobori N, Ueda S, Uwahodo Y, Kikuchi T. Cognitive dysfunction and histological findings in rats with chronic-stage contusion and diffuse axonal injury. Brain Res Brain Res Protoc 1998;3:100-6.

49.Lebedev V V, Krylov V V. [Remarks on the pathogenesis of brain contusions occurring by a counterimpact mechanism in the acute period of their development]. Zh Vopr Neirokhir Im N N Burdenko 1998:22-6.

50.Steiner J, Rafols D, Park HK, Katar MS, Rafols JA, Petrov T. Attenuation of iNOS mRNA exacerbates hypoperfusion and upregulates endothelin-1 expression in hippocampus and cortex after brain trauma. Nitric Oxide 2004;10:162-9.

51.Kallakuri S, Kreipke CW, Schafer PC, Schafer SM, Rafols JA. Brain cellular localization of endothelin receptors $A$ and $B$ in a rodent model of diffuse traumatic brain injury. Neuroscience 2010;168:820-30. 52.Schwarzmaier SM, Kim S-W, Trabold R, Plesnila N. Temporal profile of thrombogenesis in the cerebral microcirculation after traumatic brain injury in mice. J Neurotrauma 2010;27:121-30.

53.Lang EW, Yip K, Griffith J, Lagopoulos J, Mudaliar Y, Dorsch NW. Hemispheric asymmetry and temporal profiles of cerebral pressure autoregulation in head injury. Journal of Clinical Neuroscience 2003;10:670-3. 54.Prat R, Markiv V, Dujovny M, Misra M. Failure of cerebral autoregulation in an experimental diffuse brain injury model. Acta Neurochir Suppl 1998;71:123-6.

55.Panerai RB. Assessment of cerebral pressure autoregulation in humans--a review of measurement methods. Physiol Meas 1998;19:305-38.

56. [Cerebral hemodynamic in acute phase of traumatic brain injury]. Anesteziol Reanimatol 2012:58-62. 57.Yokobori S, Watanabe A, Matsumoto G, Onda H, Masuno T, Fuse A, Kushimoto S, Yokota H. Time course of recovery from cerebral vulnerability after severe traumatic brain injury: a microdialysis study. J Trauma 2011;71:1235-40.

58.Belli A, Sen J, Petzold A, Russo S, Kitchen N, Smith M. Metabolic failure precedes intracranial pressure rises in traumatic brain injury: a microdialysis study. Acta Neurochir Wien. 2008;150:461-9; discussion 470.

59. Costa T, Constantino LC, Mendonça BP, Pereira JG, Herculano B, Tasca CI, Boeck CR. N-methyl-Daspartate preconditioning improves short-term motor deficits outcome after mild traumatic brain injury in mice. J Neurosci Res 2010;88:1329-37.

60.Zlotnik A, Sinelnikov I, Gruenbaum BF, Gruenbaum SE, Dubilet M, Dubilet E, Leibowitz A, Ohayon S, Regev A, Boyko M, Shapira Y, Teichberg VI. Effect of glutamate and blood glutamate scavengers oxaloacetate and pyruvate on neurological outcome and pathohistology of the hippocampus after traumatic brain injury in rats. Anesthesiology 2012;116:73-83.

61.Wang Y, Song J-H, Denisova J V, Park W-M, Fontes JD, Belousov AB. Neuronal gap junction coupling is regulated by glutamate and plays critical role in cell death during neuronal injury. J Neurosci 2012;32:71325. 
62.Zlotnik A, Gruenbaum SE, Artru AA, Rozet I, Dubilet M, Tkachov S, Brotfain E, Klin Y, Shapira Y, Teichberg VI. The neuroprotective effects of oxaloacetate in closed head injury in rats is mediated by its blood glutamate scavenging activity: evidence from the use of maleate. J Neurosurg Anesthesiol 2009;21:235-41.

63.Bullock R, Zauner A, Woodward JJ, Myseros J, Choi SC, Ward JD, Marmarou A, Young HF. Factors affecting excitatory amino acid release following severe human head injury. J Neurosurg 1998;89:507-18.

64.Han R-Z, Hu J-J, Weng Y-C, Li D-F, Huang Y. NMDA receptor antagonist MK-801 reduces neuronal damage and preserves learning and memory in a rat model of traumatic brain injury. Neurosci Bull 2009;25:367-75.

65.Yoles E, Muller S, Schwartz M. NMDA-receptor antagonist protects neurons from secondary degeneration after partial optic nerve crush. J Neurotrauma 1997;14:665-75.

66.Maeda T, Katayama Y, Kawamata T, Koyama S, Sasaki J. Ultra-early study of edema formation in cerebral contusion using diffusion MRI and ADC mapping. Acta Neurochir Suppl 2003;86:329-31.

67.Hillered L, Vespa PM, Hovda DA. Translational neurochemical research in acute human brain injury: the current status and potential future for cerebral microdialysis. J Neurotrauma 2005;22:3-41.

68.Le Roux PD, Newell DW, Lam AM, Grady MS, Winn HR. Cerebral arteriovenous oxygen difference: a predictor of cerebral infarction and outcome in patients with severe head injury. J Neurosurg 1997;87:1-8.

69.Valadka AB, Gopinath SP, Contant CF, Uzura M, Robertson CS. Relationship of brain tissue PO2 to outcome after severe head injury. Crit Care Med 1998;26:1576-81.

70.Van den Brink WA, Van Santbrink H, Steyerberg EW, Avezaat CJ, Suazo JA, Hogesteeger C, Jansen WJ, Kloos LM, Vermeulen J, Maas AI. Brain oxygen tension in severe head injury. Neurosurgery 2000;46:868-76; discussion 876-8.

71.Patro A, Mohanty S. Pathophysiology and treatment of traumatic brain edema. The Indian Journal of Neurotrauma 2009;6:11-5.

72.Barker-Collo SL, Starkey N, Kahan M, Theadom A, Feigin V. Computerised tomography indices of raised intracranial pressure and traumatic brain injury severity in a New Zealand sample. N Z Med J 2012;125:92-4. 73.Egea-Guerrero JJ, Gordillo-Escobar E, Revuelto-Rey J, Enamorado-Enamorado J, Vilches-Arenas A, Pacheco-Sánchez M, Domínguez-Roldán JM, MurilloCabezas F. Clinical variables and neuromonitoring information intracranial pressure and brain tissue oxygenation. as predictors of brain-death development after severe traumatic brain injury. Transplant Proc 2012;44:2050-2.

74.Frutos Bernal E, Rubio Gil FJ, Martín Corral JC, Marcos Prieto LA, González Robledo J. Prognostic factors in severe traumatic brain injury. Med Intensiva 2012.

75.Abdalla Mohamed A, Ahmed Ibrahim W, Fayez Safan T. Hemodynamic and intracranial pressure changes in children with severe traumatic brain injury. EgJA 2011;27:273-8.

76.Geeraerts T, Menon DK. [Does intracranial pressure monitoring improve outcome after severe traumatic brain injury?]. Ann Fr Anesth Reanim 2010;29:e171-5. 77.Armonda RA, Tigno TA, Hochheimer SM, Stephens FL, Bell RS, Vo AH, Severson MA, Marshall SA, Oppenheimer SM, Ecker R, Razumovsky A. Posttraumatic vasospasm and intracranial hypertension after wartime traumatic brain injury. Perspectives in Medicine 2012;1:261-4.

78.Zeng T, Gao L. Management of patients with severe traumatic brain injury guided by intraventricular intracranial pressure monitoring: a report of 136 cases. Chin J Traumatol 2010;13:146-51.

79. Mitchell P, Gregson BA, Vindlacheruvu RR, Mendelow AD. Surgical options in ICH including decompressive craniectomy. J Neurol Sci 2007;261:8998.

80.Holmin S, Mathiesen T. Biphasic edema development after experimental brain contusion in rat. Neuroscience Letters 1995;194:97-100.

81.Harting MT, Smith CT, Radhakrishnan RS, Aroom KR, Dash PK, Gill B, Cox Jr. CS. Regional Differences in Cerebral Edema After Traumatic Brain Injury Identified by Impedance Analysis. Journal of Surgical Research 2010;159:557-64.

82.Unterberg AW, Stover J, Kress B, Kiening KL. Edema and brain trauma. Neuroscience 2004;129:10219.

83. Kawamata T, Katayama Y, Aoyama N, Mori $\mathrm{T}$. Heterogeneous mechanisms of early edema formation in cerebral contusion: diffusion MRI and ADC mapping study. Acta Neurochir Suppl 2000;76:9-12.

84.Katayama Y, Kawamata T. Edema fluid accumulation within necrotic brain tissue as a cause of the mass effect of cerebral contusion in head trauma patients. Acta Neurochir Suppl 2003;86:323-7.

85.Karim AHA, Jalaluddin WMS, Ghani ARI. Computed Tomography Perfusion Imaging on Traumatic Cerebral Contusion: A Preliminary Report. Malaysian Journal of Medical Sciences 2010;17:51-6. 86.Katayama Y, Becker DP, Tamura T, Hovda DA. Massive increases in extracellular potassium and the indiscriminate release of glutamate following concussive brain injury. J Neurosurg 1990;73:889-900. 
DOI: 10.2478/romneu-2013-0001

87.Eriksson EA, Barletta JF, Figueroa BE, Bonnell BW, Vanderkolk WE, McAllen KJ, Ott MM. Cerebral perfusion pressure and intracranial pressure are not surrogates for brain tissue oxygenation in traumatic brain injury. Clinical Neurophysiology 2012;123:125560.

88.Liao K-H, Chang C-K, Chang H-C, Chang K-C, Chen C-F, Chen T-Y, Chou C-W, Chung W-Y, Chiang Y-H, Hong K-S, Hsiao S-H, Hsu Y-H, Huang H-L, Huang S-C, Hung C-C, Kung S-S, Kuo KN, Li $\mathrm{K}-\mathrm{H}$, Lin J-W, Lin T-G, Lin C-M, Su C-F, Tsai M-T, Tsai S-H, Wang Y-C, Yang T-Y, Yu K-F, Chiu W-T. Clinical practice guidelines in severe traumatic brain injury in Taiwan. Surgical Neurology 2009;72, Supple:S66-S73.

89.Li LM, Timofeev I, Czosnyka M, Hutchinson PJA. Review article: the surgical approach to the management of increased intracranial pressure after traumatic brain injury. Anesth Analg 2010;111:736-48.

90.Stevens RD, Huff JS, Duckworth J, Papangelou A, Weingart SD, Smith WS. Emergency neurological life support: intracranial hypertension and herniation. Neurocrit Care 2012;17 Suppl 1:S60-5.

91.Wijayatilake DS, Shepherd SJ, Sherren PB. Updates in the management of intracranial pressure in traumatic brain injury. Curr Opin Anaesthesiol 2012;25:540-7. 92.Bor-Seng-Shu E, Figueiredo EG, Amorim RLO, Teixeira MJ, Valbuza JS, De Oliveira MM, Panerai RB. Decompressive craniectomy: a meta-analysis of influences on intracranial pressure and cerebral perfusion pressure in the treatment of traumatic brain injury. J Neurosurg 2012;117:589-96.

93.Kenning TJ, Gandhi RH, German JW. A comparison of hinge craniotomy and decompressive craniectomy for the treatment of malignant intracranial hypertension: early clinical and radiographic analysis. Neurosurg Focus 2009;26:E6.

94.Stiver SI. Complications of decompressive craniectomy for traumatic brain injury. Neurosurg Focus 2009;26:E7. 